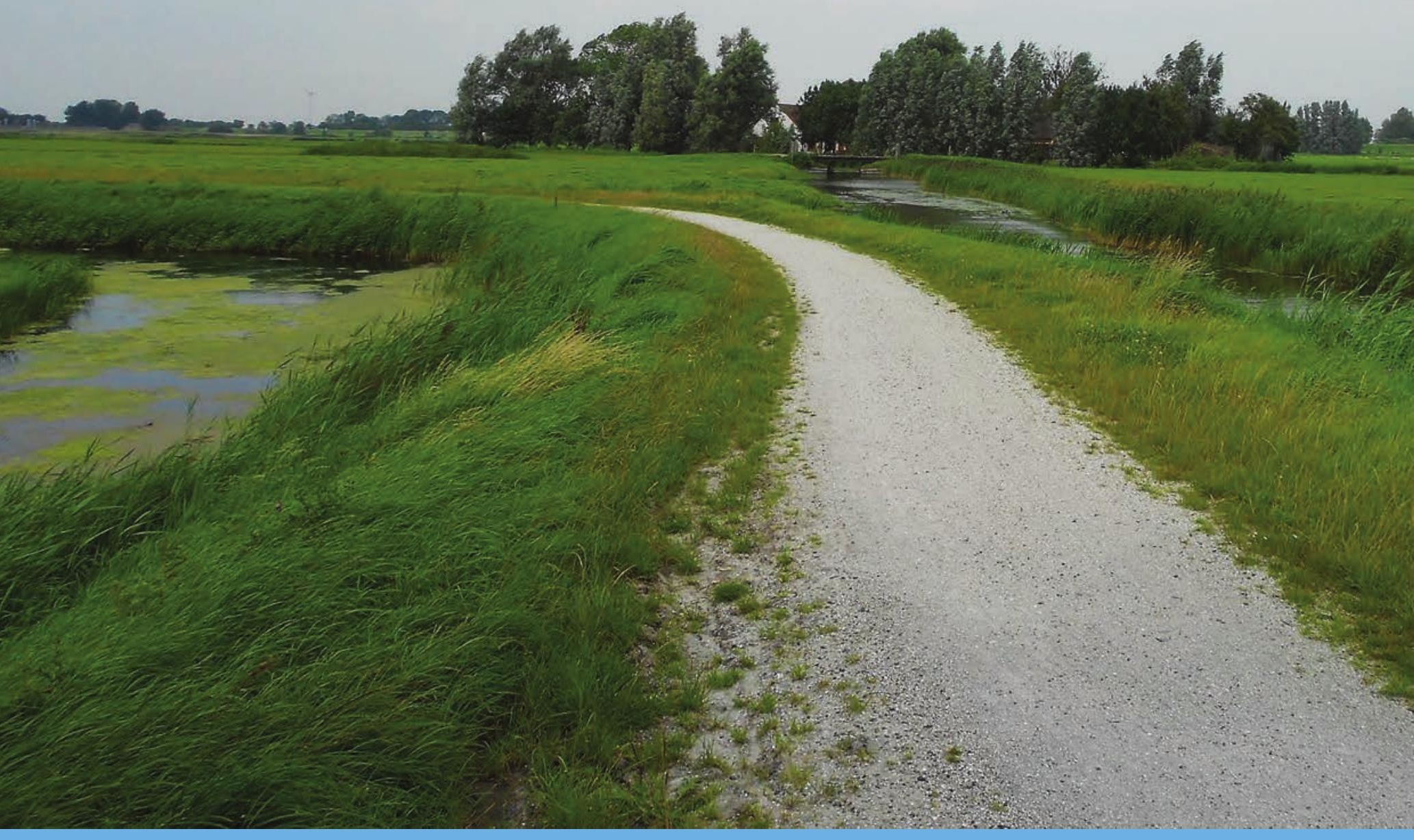

\title{
Woningbouw Abbekerk
}

Effect op weidevogelgrasland in open landschap

A.G.M. Schotman

A LTERRA

WAEENINGENUR 



\section{Woningbouw Abbekerk}

Effect op weidevogelgrasland in open landschap

A.G.M. Schotman

Dit onderzoek is uitgevoerd door Alterra Wageningen UR in opdracht van de gemeente Medemblik.

Alterra Wageningen UR

Wageningen, juli 2016

Alterra-rapport 2732

ISSN 1566-7197 
Schotman, A.G.M., 2016. Woningbouw Abbekerk; Effect op weidevogelgrasland in open landschap. Wageningen, Alterra Wageningen UR (University \& Research centre), Alterra-rapport 2732. 24 blz.; 8 fig.; 3 tab.; 6 ref.

De gemeente Medemblik wil in Abbekerk woningbouw realiseren. Hiervoor zijn drie scenario's met twee bouwfasen. Deze woningbouw is strijdig met de provinciale ruimtelijke verordening, artikel 25. Het te bebouwen gebied is op kaart gezet als 'weidevogelleefgebied'. Een bestemmingsplan mag daar alleen woningbouw toelaten als er van 'netto geen verstoord' weidevogelgebied sprake is. Uit het onderzoek blijkt dat in de eerste bouwfase van de drie scenario's het netto verstoorde oppervlak varieert van 2,9 tot 9,4 ha en het aantal verstoorde gruttoterritoria (2014) daarin van 0 tot 4 . Formeel is er dus netto-verstoring. In een inbreidingslocatie is dit niet het geval. Er worden argumenten aangevoerd dat er in ecologische zin geen sprake is van verstoring van het door het beleid beoogde weidevogelkerngebied, o.a. omdat de gebieden op de kaart in 2014 al niet voldeden aan de criteria en in 2016 ook niet.

Trefwoorden: weidevogelgrasland in open landschap, weidevogelleefgebied, weidevogelkerngebied woningbouw

Dit rapport is gratis te downloaden van http://dx.doi.org/10.18174/386339 of op www.wageningenUR.nl/alterra (ga naar 'Alterra-rapporten' in de grijze balk onderaan). Alterra Wageningen UR verstrekt geen gedrukte exemplaren van rapporten.

@) 2016 Alterra (instituut binnen de rechtspersoon Stichting Dienst Landbouwkundig Onderzoek), Postbus 47, 6700 AA Wageningen, T 03174807 00, E info.alterra@wur.nl, www.wageningenUR.nl/alterra. Alterra is onderdeel van Wageningen UR (University \& Research centre).

- Overname, verveelvoudiging of openbaarmaking van deze uitgave is toegestaan mits met duidelijke bronvermelding.

- Overname, verveelvoudiging of openbaarmaking is niet toegestaan voor commerciële doeleinden en/of geldelijk gewin.

- Overname, verveelvoudiging of openbaarmaking is niet toegestaan voor die gedeelten van deze uitgave waarvan duidelijk is dat de auteursrechten liggen bij derden en/of zijn voorbehouden.

Alterra aanvaardt geen aansprakelijkheid voor eventuele schade voortvloeiend uit het gebruik van de resultaten van dit onderzoek of de toepassing van de adviezen.

Alterra-rapport 2732 | ISSN 1566-7197

Foto omslag: Panoramio/Michail Bakker 


\section{Inhoud}

$\begin{array}{ll}\text { Samenvatting } & 5\end{array}$

$\begin{array}{lll}1 & \text { Aanleiding } & 7\end{array}$

$\begin{array}{lll}1.1 & \text { Probleemstelling } & 7\end{array}$

1.2 Achtergrond woningbouwbehoefte $\quad 7$

1.3 Natuurbeheerplan 2016 \& weidevogelkerngebieden $\quad 8$

1.4 Provinciaal Ruimtelijke Verordening 10

$\begin{array}{lll}1.5 & \text { Projectdoelstelling } & 11\end{array}$

2

$\begin{array}{ll}\text { Aanpak } & 12\end{array}$

2.1 Scenario's voor woningbouw $\quad 12$

$\begin{array}{lll}2.2 & \text { Netto geen verstoring } & 13\end{array}$

2.3 Compensatie 13

$\begin{array}{lll}2.4 & \text { Begrenzing weidevogelkerngebieden } & 14\end{array}$

3

$\begin{array}{ll}\text { Netto-verstoring } & 15\end{array}$

3.1 Netto-verstoring in drie bouwscenario's $\quad 15$

$\begin{array}{ll}3.2 & \text { Netto-verstoring plan Roskam } \\ \end{array}$

$\begin{array}{llr}4 & \text { Compensatie } & 18\end{array}$

$5 \quad$ Weidevogelkerngebieden bij Abbekerk $r$

$\begin{array}{ll}\text { Literatuur } & \mathbf{2 1}\end{array}$

$\begin{array}{lll}\text { Bijlage } 1 \text { Uitvoeringsregeling natuurcompensatie Noord-Holland } & 22\end{array}$ 



\section{Samenvatting}

De gemeente Medemblik wil graag woningbouw realiseren in aansluiting op de kern Abbekerk. Zij heeft daarvoor op de voorkeurslocaties grondposities verworven. Het beleid van de gemeente Medemblik is erop gericht om in de kernen te bouwen voor de eigen woningbehoefte. Als gevolg van het stagneren van de economie en de woningmarkt is er in de afgelopen jaren in Abbekerk niet gebouwd. Hierdoor is er ten opzichte van de behoefte een achterstand ontstaan. Aan beide kanten van Abbekerk sluit een provinciaal weidevogelleefgebied aan op de bebouwde kom. De Provinciale Ruimtelijke Verordening (PRV) verhindert het ontwikkelen van een bestemmingsplan met woningbouw in een weidevogelleefgebied. De gemeente staat op het standpunt dat er bij de aanwijzing van beide locaties tot weidevogelleefgebied door de provincie onvoldoende rekening is gehouden met het belang van woningbouw in de kern Abbekerk.

Het gaat slecht met de weidevogels in Nederland en Noord-Holland. Dit is de reden dat de provincie in 2014 zogenaamde weidevogelleefgebieden heeft aangewezen en voorzien van een planologische bescherming via de Provinciaal Ruimtelijke Verordening (PRV). De basis voor de vigerende kaarten met weidevogelleefgebied behorend bij de PRV zijn de vorige natuurbeheerplannen. Echter, het Natuurbeheerplan 2016 is op een groot aantal punten gewijzigd ten opzichte van het Natuurbeheerplan 2015. De begrenzing van het "A11.01 weidevogelgrasland in open landschap" dan wel weidevogelleefgebied is aangepast als gevolg van de reeds in de Agenda Groen aangekondigde 'kerngebiedenbenadering'. Er is 20.000 ha weidevogelleefgebied geschrapt.

Het doel van de kerngebiedenbenadering is dat weidevogelpopulaties beter worden beschermd door méér beheer- en inrichtingsinspanningen te leveren, op een beperkter areaal. Om de begrenzingen van de leefgebieden voor weidevogels in het open grasland te bepalen, gebruikt de provincie de weidevogelkerngebieden die uit onderzoek van Alterra kwamen. De feitelijke begrenzing in het natuurbeheerplan 2016 wijkt af van de door Alterra geadviseerde kerngebieden. De reden is dat lokale deskundigen nog een aantal voorstellen voor aanpassingen hebben gedaan. Verder is besloten de planologisch te beschermen gebieden te begrenzen met de grenzen van de provinciale weidevogeltelgebieden. Het uiteindelijke weidevogelgrasland in open landschap bij Abbekerk wijkt daardoor af van zowel het advies van Alterra als van dat van Landschap Noord-Holland. Een aantal artikelen in de PRV is in 2015 gewijzigd, waaronder artikel 25, dat over weidevogelgrasland in open landschapen gaat. Een 'weidevogelgrasland in open landschap' uit het Natuurbeheerplan 2016 heet 'weidevogelleefgebied' in de PRV: "In de terminologie van de kerngebiedenbenadering in NoordHolland zijn de A11.01 gebieden de "(agrarische) weidevogelleefgebieden" (brief Provincie NoordHolland 598719/775152). In ambtelijk overleg bleek dat het schrappen uit de PRV-kaart van 20.000 ha weidevogelleefgebied zijn beslag nog moet krijgen. Echter, het college van Gedeputeerde Staten (GS) van Noord-Holland vindt het van belang om te onderzoeken of deze gebieden waaronder die bij Abbekerk - om een andere reden dan weidevogelbescherming beschermd zouden moeten blijven, bijvoorbeeld vanwege landschappelijke of cultuurhistorische kwaliteiten. Dit onderzoek vindt plaats of gaat nog plaatsvinden. Tot die tijd wil GS in de provinciaal ruimtelijke verordening de 'ruime' begrenzing van het weidevogelleefgebied blijven hanteren, om zodoende geen ruimtelijke ontwikkelingen mogelijk te maken die wellicht vanuit landschappelijk of cultuurhistorisch perspectief ongewenst zijn. Woningbouw in Abbekerk kan niet gezien worden als groot openbaar belang en is niet in het kader van een 'ruimte voor ruimte'-regeling, afgezien van een klein inbreidingsvoorstel. Een bestemmingsplan dat betrekking heeft op weidevogelleefgebied kan volgens de PRV niet voorzien in de mogelijkheid van nieuwe bebouwing, tenzij die ingreep 'netto geen verstoring' van het weidevogelleefgebied geeft. Met netto-verstoring wordt de extra verstoring bedoeld, die een ingreep heeft op een weidevogelgrasland in open landschap, bovenop de al bestaande verstoring in het gebied door gebouwen, wegen en dergelijke. Gedeputeerde Staten kunnen jaarlijks de kaart van de provinciaal ruimtelijke verordening met het weidevogelgrasland in open landschap dan wel weidevogelleefgebied aanpassen. Dit is nog geen praktijk. 
Doel van dit advies is de gemeente te ondersteunen met feiten bij het overleg met de provincie en de keuze tussen de voorkeurslocatie en de alternatieve locatie. Gevraagd is om:

- te beoordelen of er een netto-aantasting optreedt van het weidevogelleefgebied dan wel weidevogelgrasland in open landschap,

- op welke wijze dit eventueel gecompenseerd kan worden en

- of het te bebouwen gebied terecht 'weidevogelgrasland in open landschap' is.

Om deze vragen te beantwoorden, zijn de oppervlaktes en aantallen grutto's bepaald in verstoringszones van bestaande bebouwing en de bebouwing in de beschreven scenario's en voor het inbreidingsplan 'Roskam'. Om te onderzoeken of de beide weidevogelleefgebieden voldoen aan de criteria hiervoor zijn de weidevogels in 2016 nogmaals geteld.

Feit is dat de gronden direct aansluitend op de bebouwde kom van Abbekerk volgens het geldende beleid weidevogelleefgebied zijn die via artikel 25 van de PRV worden beschermd. Een

bestemmingsplan wijzigen ten behoeve van woningbouw is alleen mogelijk als er sprake is van 'netto geen verstoring' van weidevogelleefgebied. Een netto verstoord gebied is een extra verstoord gebied bovenop gebied dat nu al verstoord is. Van een werkelijke verstoring in ecologische zin is pas sprake als daar ook weidevogels zitten die het gevoeligst zijn. De grutto is daarvoor de beste indicator, omdat de tureluur minder gevoelig is en de slobeend niet gevoelig voor beslotenheid door bebouwing en opgaande begroeiing.

Het netto verstoorde oppervlak varieert in de eerste bouwfase van de drie scenario's van 2,9 tot 9,4 ha en het aantal verstoorde gruttoterritoria (2014) daarin van 0 tot 4 . Hoewel er, afgezien van plan Roskam, volgens de regelgeving in hectares gerekend dus van een netto verstorend effect gesproken kan worden, zijn er ten minste drie argumenten aan te voeren dat er soms feitelijk geen sprake is van een netto-effect:

1. Het aantal verstoorde grutto's, als indicator voor de meest gevoelige soort, is nul in de scenario's 2 en 3. Drie gruttoterritoria liggen al binnen de bestaande verstoorde zone van scenario 1.

2. Het verstoorde gebied voldoet niet aan de eisen van een weidevogelkerngebied zoals bedoeld in het NBP en zal daar ook nooit aan kunnen voldoen (zie verder hoofdstuk 5).

3. Bij een evaluatie van de weidevogelleefgebiedenkaart in de provinciaal ruimtelijke verordening zullen de weidevogelleefgebieden grenzend aan Abbekerk verdwijnen of ingekrompen moeten worden.

Aangezien compensatie nog niet aan de orde is, wordt hierop verder niet ingegaan. Beide telgebieden voldeden op basis van de gegevens van 2014 al niet meer aan de daarvoor geldende eisen. De vraag was of dat anno 2016 nog steeds het geval is.

Geen van beide telgebieden voldoet in 2016 aan deze criteria. De criteria zijn vrij rigide toegepast op gehele telgebieden. Een kaartbeeld dat de verspreiding van de vogels weergeeft, zegt veel meer dan een 'netto verstoord gebied' bij de huidige wijze van begrenzen. Alterra heeft de provincie in 2014 grenzen geadviseerd, gebaseerd op de kern van de verspreiding van de soorten, dus de gebiedsdelen waar de dichtheden uit de criteria gehaald worden. Zulke kernen zullen nog bestaan binnen de onderzochte telgebieden. Voor behoud van weidevogels is het zaak die kernen, voorzien van een buffer van 400-600 m, te behouden. 


\section{$1 \quad$ Aanleiding}

\section{$1.1 \quad$ Probleemstelling}

De gemeente Medemblik wil graag woningbouw realiseren in aansluiting op de kern Abbekerk. Zij heeft daarvoor een voorkeurslocatie aan de noordwestkant en een alternatieve locatie aan de zuidoostkant op het oog en grondposities verworven. Aan beide kanten sluit een provinciaal weidevogelleefgebied vrijwel aan op de bebouwde kom. De Provinciale Ruimtelijke Verordening (PRV) verhindert het ontwikkelen van een bestemmingsplan met woningbouw in een weidevogelleefgebied.

\subsection{Achtergrond woningbouwbehoefte}

Het beleid van de gemeente Medemblik is erop gericht om in de kernen te bouwen voor de eigen woningbehoefte. Dit is van belang om te voorkomen dat jongeren, gezinnen en senioren noodgedwongen naar elders moeten verhuizen. Het bouwen voor eigen behoefte zorgt er ook voor dat de voorzieningen zo veel mogelijk behouden blijven, wat belangrijk is voor de leefbaarheid in de kernen.

Ook voor Abbekerk heeft de gemeente een woningbouwprogramma dat is afgestemd op de eigen behoefte. Deze woningbehoefte wordt in overleg met de provincie vastgesteld in regionaal verband. Om voldoende woningen te kunnen realiseren, heeft de gemeente op twee locaties gronden verworven. Achtereenvolgend kunnen de locaties Nieuwe Veld en Vekenweg/Reigersweg ontwikkeld worden. In de gemeentelijke structuurvisie hebben deze locaties respectievelijk een plancapaciteit van ca. 60 en ca. 80 woningen. De regionale Woonvisie, die momenteel geactualiseerd wordt, zal mede bepalend zijn voor de nadere invulling. Vooralsnog wordt rekening gehouden met een gemengd programma voor starters, gezinnen en senioren in zowel de sociale huursector als de koopsector.

Bij de ontwikkeling van beide locaties geldt dat op een zorgvuldige wijze aangesloten dient te worden op de reeds bestaande bebouwing en op het omliggende landschap. Voor beide locaties geldt ook dat de verkeersontsluiting zo min mogelijk overlast dient te veroorzaken op de bestaande wegen.

Als gevolg van het stagneren van de economie en de woningmarkt is er in de afgelopen jaren in Abbekerk niet gebouwd. Hierdoor is er ten opzichte van de behoefte een achterstand ontstaan. De gemeente onderkent de urgentie om deze achterstand in de komende jaren weer in te lopen.

Conform het beleid wilde de gemeente als eerste de locatie Nieuwe veld ontwikkelen. De bewoners van verschillende buurten in Abbekerk hebben de gemeenteraad gevraagd om te onderzoeken of het mogelijk is om eerst de locatie Vekenweg/Reigersweg te ontwikkelen. De gemeenteraad heeft dit verzoek gehonoreerd.

De gemeente staat op het standpunt dat er bij de aanwijzing van beide locaties tot weidevogelgebied door de provincie onvoldoende rekening is gehouden met het belang van woningbouw in de kern Abbekerk. Om de belangen van de weidevogels goed in beeld te krijgen, heeft de gemeente aan Alterra opdracht gegeven om hier onderzoek naar te doen. De resultaten van dit onderzoek wil de gemeente gebruiken om te komen tot een goede afweging van de belangen van de woningbouw en de belangen van de weidevogels op beide locaties. Op basis van dit onderzoek zal de gemeente ook reageren op het ontwerp Natuurbeheerplan 2017 en de aanpassing van de provinciale verordening. 


\subsection{Natuurbeheerplan 2016 \& weidevogelkerngebieden}

Het gaat slecht met de weidevogels in Nederland en Noord-Holland. Dit is de reden dat de provincie in 2014 zogenaamde weidevogelleefgebieden heeft aangewezen en voorzien van een planologische bescherming. De basis voor de vigerende kaarten met weidevogelleefgebied behorend bij de Provinciaal Ruimtelijke Verordening zijn de vorige natuurbeheerplannen. Het Natuurbeheerplan 2016 is op een groot aantal punten gewijzigd ten opzichte van het natuurbeheerplan 2015. De begrenzing van het weidevogelgrasland in open landschap dan wel weidevogelleefgebied is aangepast als gevolg van de reeds in de Agenda Groen aangekondigde 'kerngebiedenbenadering'. Er is 20.000 ha weidevogelleefgebied geschrapt. Het doel van de kerngebiedenbenadering is dat weidevogelpopulaties beter worden beschermd door méér beheer- en inrichtingsinspanningen te leveren, op een beperkter areaal.

Het leefgebied open grasland is kenmerkend voor Noord-Holland: open landschappen met overwegend grasland, waarvan een substantieel deel vochtig en kruidenrijk is. Het leefgebied wordt doorsneden met fijnmazige watergangen. Een aantal kritische weidevogelsoorten (zoals grutto) zoekt altijd de meest open delen van het landschap en mijdt wegen, bebouwing en opgaande begroeiing. Ze zijn daarom afhankelijk van dit leefgebied. Andere niet-kritische soorten (zoals kievit en scholekster) zijn toleranter voor 'beslotenheid'. Alterra heeft de provincie (Siersema et al., 2013 Buij et al., 2013 en Schotman et al., 2014) geadviseerd over kerngebieden voor weidevogels. Om de begrenzingen van de leefgebieden van zowel kritische als niet-kritische soorten in het open grasland te bepalen, gebruikt de provincie de weidevogelkerngebieden die uit dit onderzoek kwamen.

In het Conceptnatuurbeheerplan 2016 heetten de beoogde kerngebieden nog "Weidevogelkerngebieden voor kritische soorten (A11.01)", in het definitieve NBP 2016 worden ze aangeduid met A11.01 weidevogelgrasland in open landschap. De passage over de selectiecriteria is ook aangepast, maar het volgende deel is gehandhaafd:

"Bij de selectie van kerngebieden zijn grutto, tureluur en slobeend als indicatorsoorten genomen: drie soorten van de natte kruidenrijke graslandgebieden met een late maaidatum. Voor het bepalen van de kerngebieden is gebruikgemaakt van soortspecifieke grenswaarden: voor slobeend ten minste 3 broedparen per 100 hectare, voor grutto ten minste 15 broedparen/100 ha, voor tureluur ten minste 10 broedparen/100 ha en tezamen ten minste 28 broedparen/100 ha. Ook heeft een kerngebied een minimale grootte van 100 ha, met enkele uitzonderingen van 50 ha. De minimale openheid is $400 \mathrm{~m}$, terwijl meer dan 600 m optimaal is."

Daarnaast zijn in het natuurbeheerplan bij de doelstellingen nog allerlei doelen en streefdoelen voor de te beheren gebieden geformuleerd over de drooglegging, de hoeveelheid kruidenrijk grasland, de mate van rust en uitgesteld maaien en het aandeel sloten met een natuurvriendelijke oever. De minimaal gewenste dichtheid van grutto is 10 paren per 100 ha, met een streven naar 25 paren per 100 ha, of grutto, tureluur en slobeend samen minimaal 50 paren per 100 ha.

Bij het Natuurbeheerplan 2016 is een separate kaart gevoegd met het weidevogelgrasland in open landschap, zowel binnen als buiten het NNN. Deze begrenzing zal worden opgenomen in de Provinciale Ruimtelijke Verordening, zodat de planologische bescherming van deze gebieden wordt geborgd (op grond van artikel 25 PRV). De feitelijke begrenzing in het natuurbeheerplan 2016 wijkt af van de door Alterra geadviseerde kerngebieden. De reden is dat lokale deskundigen (Visbeen et al., 2014) nog een aantal voorstellen hebben gedaan die tot aanpassingen hebben geleid. Verder is besloten de planologisch te beschermen gebieden te begrenzen met de grenzen van de provinciale weidevogeltelgebieden. Het uiteindelijke weidevogelgrasland in open landschap bij Abbekerk wijkt daardoor af van zowel het advies van Alterra als van dat van Landschap Noord-Holland (zie Figuur 2 \& 3). 


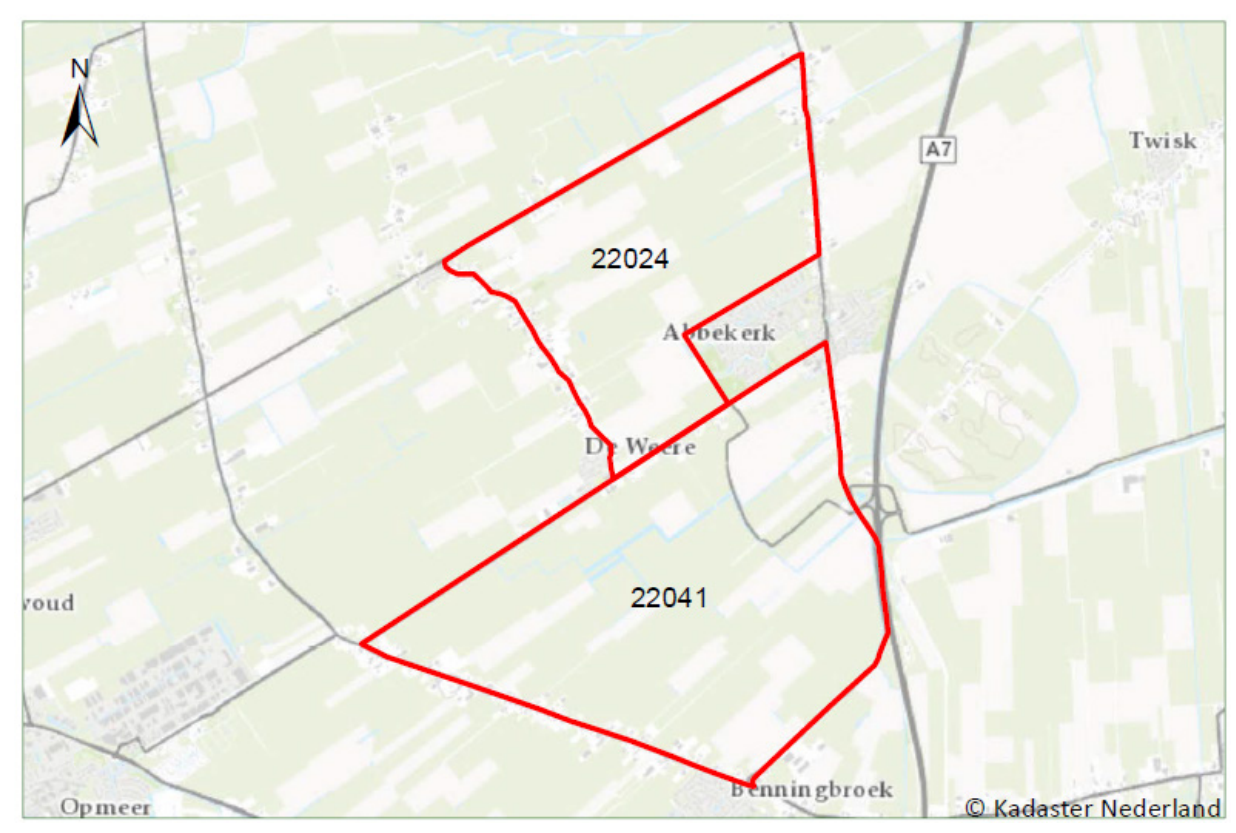

Figuur 1 Telgebieden voor weidevogels ten westen van Abbekerk.

Herkomst begrenzing weidevogelleefgebied

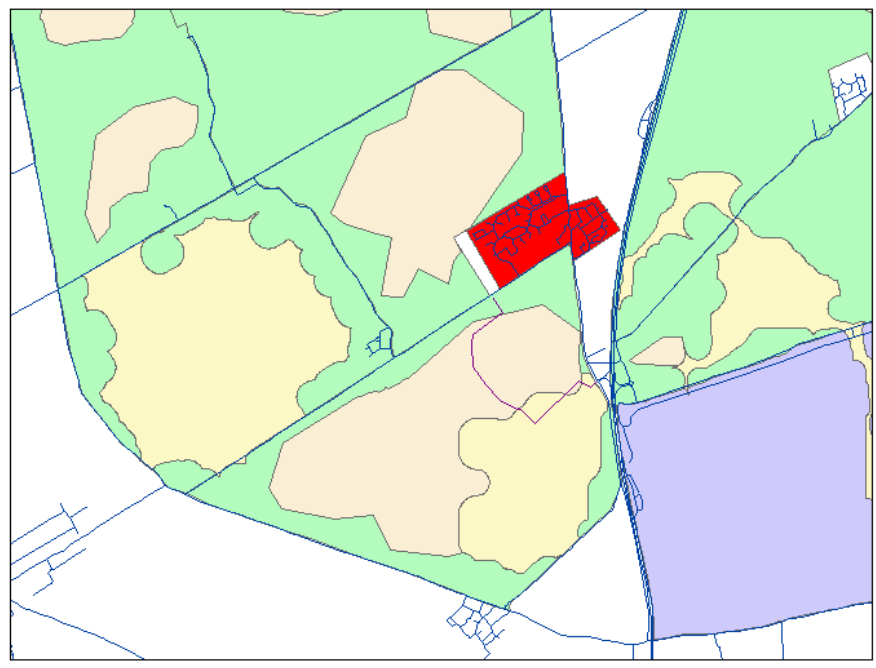

Legenda

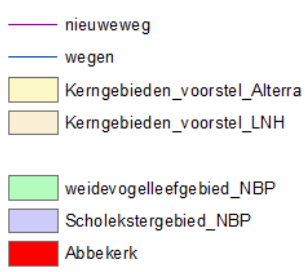

Figuur 2 Ligging van de oorspronkelijk door Alterra en Landschap Noord-Holland geadviseerde en de uiteindelijke weidevogelleefgebieden of 'weidevogelgrasland in open landschap' in het definitieve Natuurbeheerplan. 


\subsection{Provinciaal Ruimtelijke Verordening}

In juni 2010 werd de Provinciale Ruimtelijke Verordening Structuurvisie (PRVS) vastgesteld. Deze is sindsdien drie keer gewijzigd. Bij de vierde wijziging, vastgesteld op 3 februari 2014, is besloten om de PRVS opnieuw vast te stellen om te voorkomen dat er een stapeling van toelichtingen zou ontstaan. Ook was het daardoor mogelijk om de naam van de PRVS te veranderen in Provinciale Ruimtelijke Verordening (PRV): deze benaming sluit beter aan bij overige provinciale verordeningen en door de term Structuurvisie te laten vervallen, is verduidelijkt dat de verordening een zelfstandig document is en dat, in tegenstelling tot de Structuurvisie Noord-Holland 2040, de verordening een bindend document is. Op 28 september 2015 is er ook een wijziging van de PRV vastgesteld door Provinciale Staten. Een aantal artikelen is daarbij gewijzigd, waaronder artikel 25 dat over weidevogelgrasland in open landschapen gaat. Een 'weidevogelgrasland in open landschap' uit het natuurbeheerplan 2016 heet 'weidevogelleefgebied' in de PRV: "In de terminologie van de kerngebiedenbenadering in Noord-Holland zijn de A11.01 gebieden de "(agrarische) weidevogelleefgebieden" (brief Provincie Noord-Holland 598719/775152).

Artikel 25 uit de Provinciaal Ruimtelijke Verordening (PRV) bevat o.a. de volgende bepalingen:

1. Een bestemmingsplan dat betrekking heeft op weidevogelleefgebied voorziet niet in:

a. de mogelijkheid van nieuwe bebouwing, anders dan binnen een bestaand bouwblok of een uitbreiding daarvan;

b. de mogelijkheid van aanleg van nieuwe weginfrastructuur;

c. de mogelijkheid van aanleg van bossen of boomgaarden;

d. de mogelijkheid verstorende activiteiten, buiten de huidige agrarische activiteiten, te verrichten die het weidevogelgrasland in open landschap verstoren;

e. de mogelijkheid werken uit te voeren die realisatie van nieuwe peilverlagingen mogelijk maken.

3. In afwijking van het eerste lid kan een bestemmingsplan wel voorzien in de in dat lid omschreven ontwikkelingen indien dit geschiedt ten behoeve van:

a. een ingreep waarvoor geen aanvaardbaar alternatief aanwezig is en waarmee bovendien een groot openbaar belang wordt gediend;

b. woningbouw indien er sprake is van de toepassing van de regeling Ruimte voor Ruimte als bedoeld in artikel 16 en waarbij de natuurdoelen leidend zijn;

c. woningbouw die bijdraagt aan een substantiële verbetering van in de directe omgeving daarvan aanwezige natuurkwaliteiten van het landschap of

d. een ingreep die netto geen verstoring van het weidevogelleefgebied geeft.

4. In aanvulling op het derde lid kan het bestemmingsplan hier alleen in voorzien indien in het bestemmingsplan wordt opgenomen:

a. op welke wijze schade aan een weidevogelleefgebied zo veel mogelijk wordt voorkomen en resterende schade wordt gecompenseerd;

b. hoe wordt geborgd dat de maatregelen ten behoeve van de compensatie als bedoeld onder a daadwerkelijk worden uitgevoerd;

c. op welke wijze aan het gestelde in artikel 13, tweede lid en artikel 14, tweede lid, wordt voldaan;

d. op welke wijze aan de ruimtelijke kwaliteitseisen als bedoeld in artikel 15 is voldaan.

5. Gedeputeerde staten kunnen, gehoord de desbetreffende commissie van provinciale staten, de begrenzing van de weidevogelleefgebieden wijzigen:

a. naar aanleiding van recente tellingen van het aantal broedparen;

b. ten behoeve van een kleinschalige ontwikkeling of

c. ten behoeve van de krachtens het derde lid gestelde regels.

Woningbouw in Abbekerk kan niet gezien worden als groot openbaar belang is en is niet in het kader van een 'ruimte voor ruimte'-regeling, afgezien van een klein inbreidingsvoorstel. Op voorhand is er geen sprake van een substantiële verbetering van de in de directe omgeving aanwezige 
natuurkwaliteiten. De gemeente is wel bereid eventuele schade aan weidevogels ruimhartig te compenseren, maar de provincie wil daar niet over in gesprek (Verslag ambtelijk overleg op 10 mei 2016). Een vraag is dan of de ingreep mogelijk netto geen verstoring van het weidevogelleefgebied geeft. Verder is de vraag of de begrenzing van de weidevogelleefgebieden niet kan worden gewijzigd. In het reeds aangehaalde ambtelijk overleg bleek dat het schrappen uit de PRV-kaart van 20.000 ha weidevogelleefgebied zijn beslag nog moet krijgen. De reden voor de aanpassing was dat "hier onvoldoende weidevogels zaten om nog verdere subsidiëring voor agrarisch beheer te rechtvaardigen. Echter, ons college [GS NH] vindt het van belang om te onderzoeken of deze gebieden - waaronder Broerdijk-Zuid/Midwoud - om een andere reden dan weidevogelbescherming beschermd zouden moeten blijven, bijvoorbeeld vanwege landschappelijke of cultuurhistorische kwaliteiten". Dit onderzoek vindt plaats of gaat nog plaatsvinden. "Tot die tijd willen wij [GS NH] in de Provinciaal Ruimtelijke Verordening de 'ruime' begrenzing van het weidevogelleefgebied blijven hanteren, om zodoende geen ruimtelijke ontwikkelingen mogelijk te maken die wellicht vanuit landschappelijk of cultuurhistorisch perspectief ongewenst zijn" (brief Provincie Noord-Holland 598719/775152).

\subsection{Projectdoelstelling}

Doel van het advies is de gemeente te ondersteunen met feiten bij het overleg met de provincie en de keuze tussen de voorkeurslocatie en de alternatieve locatie. Gevraagd is om:

- te beoordelen of er een netto-aantasting optreedt van het weidevogelleefgebied dan wel weidevogelgrasland in open landschap,

- op welke wijze dit eventueel gecompenseerd kan worden en

- of het te bebouwen gebied terecht 'weidevogelgrasland in open landschap' is.

Bij overleg tussen de gemeente en de provincie kwam de suggestie om ook de woningbouwlocatie "Roskam" aan de Dorpsstraat te Abbekerk te onderzoeken. De provincie heeft gevraagd om door middel van onderzoek aan te tonen dat er inderdaad netto geen verstorend effect is.

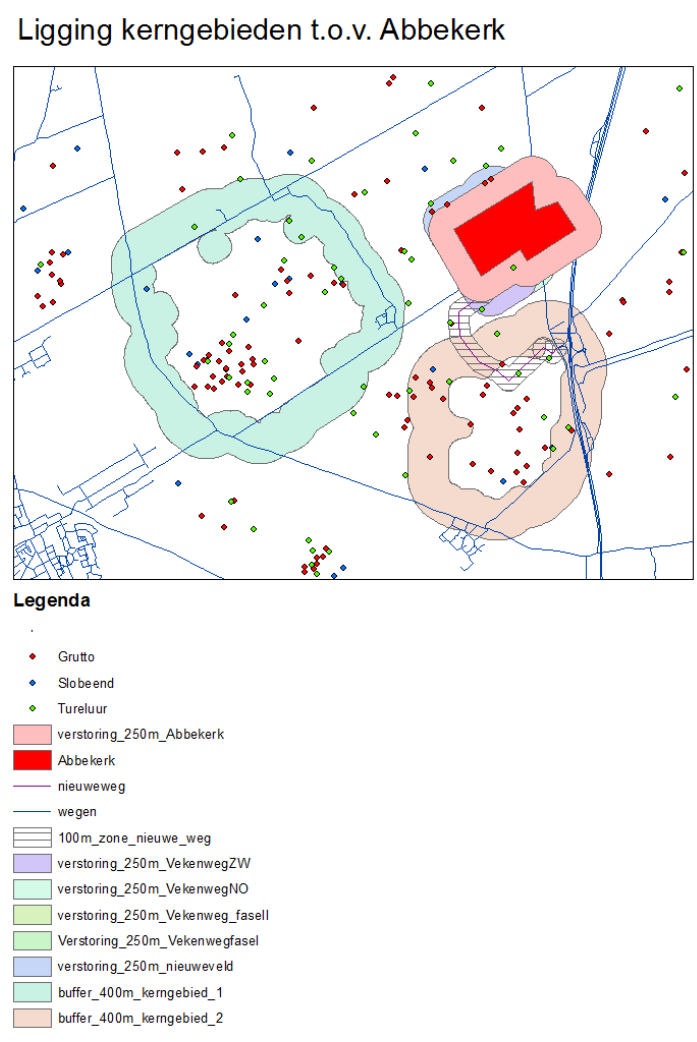

Figuur 3 Ligging door Alterra geadviseerde kerngebieden bij Abbekerk met verstoringszones inclusief nieuwbouw, de verspreiding van de drie selectiesoorten in 2014 en een buffer van $400 \mathrm{~m}$ rond de kerngebieden. 


\section{Aanpak}

\subsection{Scenario's voor woningbouw}

De gemeente Medemblik heeft drie scenario's uitgewerkt die alle bestaan uit twee bouwfases (zie Figuur 4). Behalve deze scenario's is er nog een mogelijkheid voor woningbouw. Deze woningbouwlocatie 'Roskam' is ter vervaging van een bestaand agrarisch bedrijf. Het gaat om de bouw van ca. 5 vrije sector-kavels. De provincie ziet hier wel kansen voor verbetering van de ruimtelijke kwaliteit in het kader van de 'Ruimte voor Ruimte-regeling' en er is naar verwachting geen netto verstorend effect in verband met de vigerende agrarische bestemming en de reeds bestaande effecten van de Dorpsstraat.

\section{Drie scenario's voor uitbreiding:}

1. Nieuwe veld, daarna Vekenweg fase I

2. Vekenweg fase I, daarna II

3. Vekenweg NO, daarna ZW

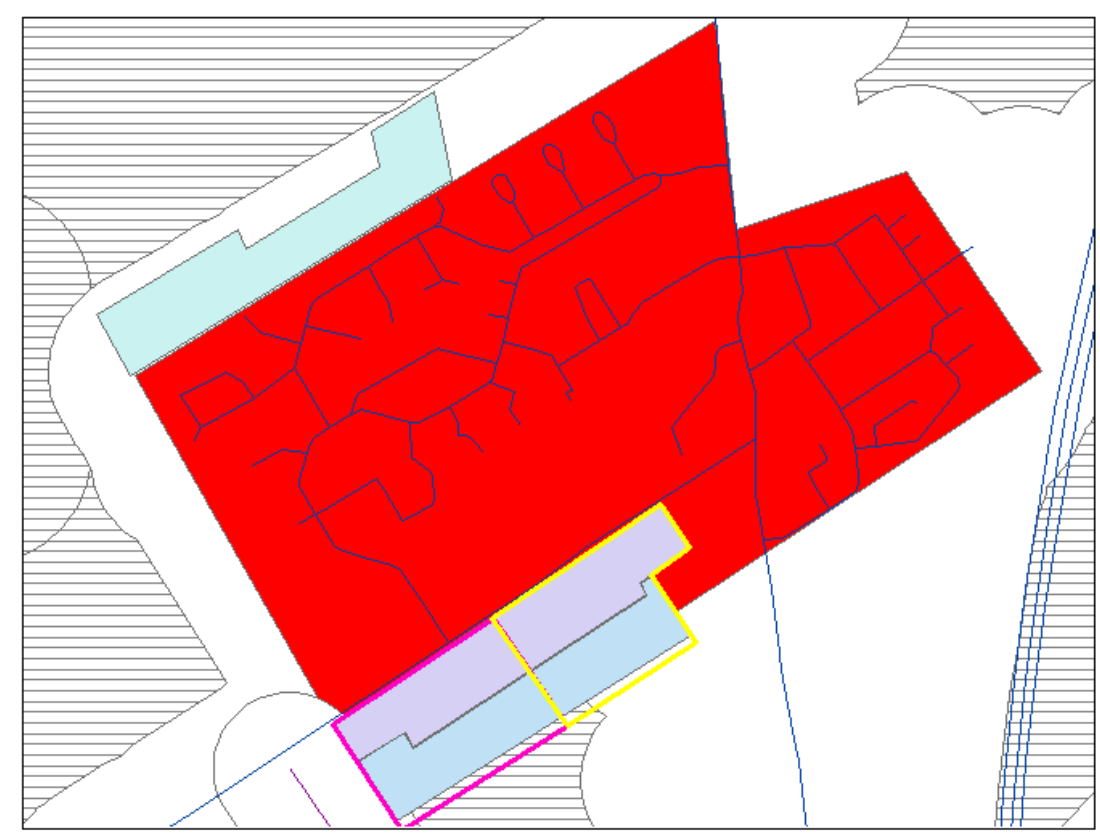

\section{Legenda}

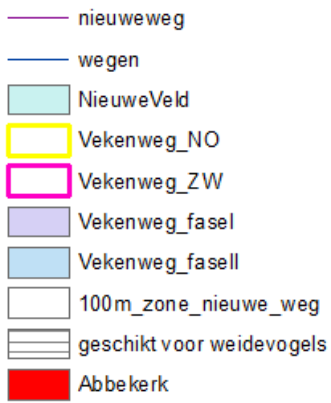

Figuur 4 Bouwscenario's Abbekerk. 


\subsection{Netto geen verstoring}

Met de term "netto geen verstoring" wordt het volgende bedoeld (bron: Provinciaal Ruimtelijke Verordening). Weidevogels houden van een rustig en open landschap. Hoge elementen of infrastructuur, zoals wegen, fietspaden, wandelpaden, bebouwing, bosschages of bomenrijen zorgen voor verstoring voor weidevogels. In de directe omgeving van dergelijke elementen zullen weinig tot geen weidevogels gaan broeden. Een fietspad dat dwars door een weiland wordt aangelegd waar nog geen verstoring is, zal een enorm verstorend effect hebben op de weidevogels die daar broeden. Wordt datzelfde fietspad naast een bomenrij of een snelweg aangelegd, dan zal het extra verstorende effect van het fietspad voor weidevogels nihil zijn. Met netto-verstoring wordt de extra verstoring bedoeld, die een ingreep heeft op een weidevogelgrasland in open landschap, bovenop de al bestaande verstoring in het gebied door gebouwen, wegen en dergelijke.

Bestaande wegen, opgaande begroeiing en bebouwing van Abbekerk hebben al een verstorend effect. De vraag is dan of en hoeveel extra bebouwing daaraan toevoegt. De wijze waarop de verstoring beschreven moet worden, is niet voorgeschreven. In dit onderzoek wordt, net als in het advieswerk (Sierdsema et al., 2013, Schotman et al., 2014) voor de provincie, gebruikgemaakt van verstoringsafstanden van verschillende landschapselementen. Als gecombineerde verstoringsafstand van bebouwing met bomen is 250 m aangehouden (Teunissen et al., 2012). Met ArcGis wordt bepaald welke oppervlakte weidevogelgrasland in open landschap er binnen een verstoringsafstand valt die nog niet door reeds bestaande landschapselementen zijn verstoord.

Een oppervlakte weidevogelgrasland in open landschap zou als het goed is ook weidevogels moeten huisvesten, maar dat is gezien de begrenzing met telgebiedgrenzen waarschijnlijk niet altijd het geval. Men zou kunnen stellen dat als er in het netto verstoorde gebied geen weidevogels aanwezig zijn, er ook niet sprake zal zijn van een netto-verstoring. Daarom is met verspreidingskaarten van weidevogels uit 2009 en 2014 bepaald hoeveel grutto's er zitten binnen die verstoorde zones. De weidevogelgegevens zijn beschikbaar gesteld door provincie en landschap Noord-Holland en in 2014 verzameld door Ecologisch Onderzoeks- en Adviesbureau Van der Goes en Groot (Hoogendoorn \& Visbeen 2014). Alleen grutto's zijn geteld, omdat veel andere weidevogels veel minder gevoelig zijn voor de nabijheid van gebouwen en opgaande begroeiing. Voor deze soorten zijn geen bruikbare verstoringsafstanden voorhanden. De kerngebieden zijn vooral geselecteerd voor grutto, tureluur en slobeend, waarvan de grutto het gevoeligst is.

De oppervlaktes en aantallen worden bepaald voor elk van de beschreven scenario's en voor het plan 'Roskam'.

\subsection{Compensatie}

Geeft een ingreep netto wel extra verstoring, dan zal indien ze toch door kan gaan, het verstorende effect gecompenseerd moeten worden. De woningbouw als bedoeld in het derde lid onder $c$ van artikel 25 van de Provinciaal Ruimtelijke Verordening heeft betrekking op 'Ruimte voor Ruimte'-projecten, waardoor weidevogelgrasland in open landschap gerealiseerd kan worden. Overige woningbouw dient te worden gecompenseerd.

Leidraad voor compensatie kan het beste de netto verstoorde oppervlakte zijn. Deze zal voor elk beschreven scenario bepaald worden. Aangezien compensatie nog niet aan de orde is, wordt op compensatie verder niet ingegaan. Zie Bijlage 1 voor richtlijnen voor compensatie in Noord-Holland. 


\subsection{Begrenzing weidevogelkerngebieden}

Gedeputeerde Staten kunnen jaarlijks de kaart van de Provinciaal Ruimtelijke Verordening met het weidevogelgrasland in open landschap dan wel weidevogelleefgebied aanpassen. De begrenzing wijzigt op basis van jaarlijkse tellingen, maar de perceelgrootte niet (artikelsgewijze toelichting PRV blz. 28.) Zoals we zagen in paragraaf 1.4 is dit nog geen praktijk.

Het weidevogelgrasland in open landschap zouden al weidevogelkerngebieden moeten zijn waarin de geformuleerde doelen al worden gehaald of moeten dat worden zoals beschreven in het Natuurbeheerplan 2016. Om als weidevogelkerngebied geselecteerd te kunnen worden, moest de dichtheid aan weidevogels voldoen aan de volgende criteria:

- de gezamenlijke dichtheid van grutto, tureluur en slobeend is ten minste 28 paren per 100 ha cultuurland,

- of de dichtheid van de grutto is ten minste 15 , tureluur 10 en slobeend 3 paren per 100 ha cultuurland.

In het definitieve natuurbeheerplan staan naast deze selectiecriteria ook minimale dichtheden en streefdichtheden geformuleerd als doelen voor weidevogelgrasland in open landschap:

- grutto minimaal 10 paren per 100 ha of

- grutto, tureluur en slobeend samen 50 paren per 100 ha.

De aangewezen gebieden staan open voor gesubsidieerd agrarisch natuurbeheer, waarbij gestreefd moet worden naar een dichtheid van 25 paren per 100 ha.

In de inleiding is al beschreven dat beide telgebieden in 2014 niet voldeden aan deze criteria. In opdracht van de gemeente Medemblik heeft het ecologisch adviesbureau Van der Goes en Groot in 2016 onderzoek gedaan in beide telgebieden om te bepalen of deze nu wel aan de criteria voldoen. Behalve aan de criteria voor de dichtheid aan weidevogels zijn er ook nog criteria met betrekking tot openheid, drooglegging, kruidenrijk grasland en rust voor weidevogels. Hierop gaat dit onderzoek verder niet in, omdat het niet waarschijnlijk is dat wel aan die criteria wordt voldaan en niet aan die voor de dichtheden van weidevogels. 


\section{$3 \quad$ Netto-verstoring}

\subsection{Netto-verstoring in drie bouwscenario's}

Feit is dat de gronden direct aansluitend op de bebouwde kom van Abbekerk volgens het geldende beleid weidevogelleefgebied zijn, die via artikel 25 van de Provinciale Ruimtelijke Verordening worden beschermd. Een bestemmingsplan wijzigen ten behoeve van woningbouw is alleen mogelijk als er sprake is van 'netto geen verstoring' van weidevogelleefgebied. Een netto verstoord gebied is een verstoord gebied extra ten opzichte van wat nu al verstoord is. Voor het aangeven van verstoord gebied zijn bufferzones rond wegen en bebouwing getekend. Door bestemming voor woningbouw gaan definitief echte hectares van de categorie weidevogelleefgebied dan wel 'weidevogelgrasland in open landschap' verloren. Als er al potenties waren om daarvan weidevogelkerngebied te maken, dan gaan die verloren. Van een werkelijke verstoring in ecologische zin is pas sprake als er ook weidevogels zitten die het gevoeligst zijn. De grutto is daarvoor de beste indicator, omdat de tureluur minder gevoelig en de slobeend niet gevoelig is voor beslotenheid door bebouwing en opgaande begroeiing. Voor de drie scenario's is het verlies in hectares door het bouwblok, indicatief op aanwijzing van de gemeente, de extra verstoorde oppervlakte (ook cumulatief) en het aantal grutto's in 2009 en 2014 binnen de verstoorde oppervlakte bepaald (Tabel 1.)

\section{Tabel 1}

Oppervlakte bouwblok en (cumulatief) extra verstoord in hectares en het aantal grutto's in verstoorde zone.

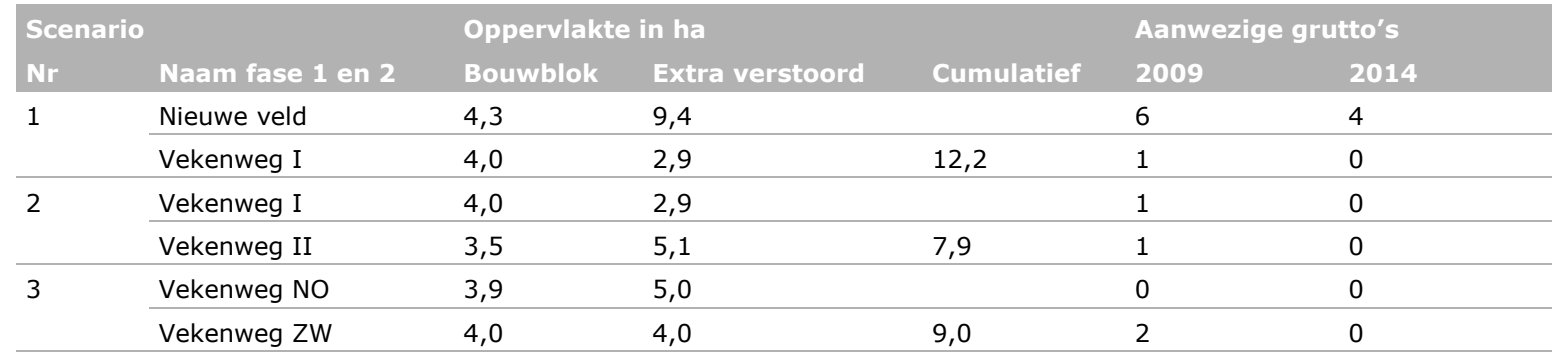

De oppervlakte in scenario 2 en 3 moet eigenlijk gelijk zijn. De bouwvlakken van scenario 3 zijn nu 0,4 ha groter, waardoor het (cumulatief) verstoorde oppervlak ook iets groter is. (Voor de ligging van het verstoord gebied per scenario en per fase zie Figuur 5 op de volgende pagina.) De unionSC* zijn hulplijnen die de grenzen van respectievelijk Abbekerk en de verstoorde $250 \mathrm{~m}$-buffers van Abbekerk en de bouwblokken weergeven.

Het netto verstoorde oppervlak varieert in de eerste bouwfase van de drie scenario's van 2,9 tot 9,4 ha en het aantal verstoorde gruttoterritoria (2014) daarin van 0 tot 4 . Fase 1 van scenario 2 en 3 scoort duidelijk beter dan realisatie van de voorkeurslocatie Nieuwe Veld van scenario 1. De scenario's 2 en 3 scoren samen ook beter qua cumulatief verstoord oppervlak, respectievelijk 7,9 en 9,0 ha, in vergelijking met scenario 1 (12,2 ha). Ook het aantal verstoorde grutto's (2014) is lager, beide 0 , tegen 4 voor scenario 1.

Hoewel er volgens de regelgeving in hectares gerekend dus van een netto verstorend effect gesproken kan worden, zijn er ten minste drie argumenten aan te voeren dat er soms feitelijk geen sprake is van een netto-effect:

1. Het aantal verstoorde grutto's, als indicator voor de gevoeligste soort, is 0 in de scenario's 2 en 3. Drie gruttoterritoria liggen al binnen de bestaande verstoorde zone.

2. Het verstoorde gebied voldoet niet aan de eisen van een weidevogelkerngebied zoals bedoeld in het NBP en zal daar ook nooit aan kunnen voldoen (zie verder hoofdstuk 5). 
3. Bij een jaarlijkse evaluatie van de weidevogelleefgebiedenkaart in de Provinciaal Ruimtelijke Verordening zullen de weidevogelleefgebieden grenzend aan Abbekerk verdwijnen of ingekrompen moeten worden.

Extra verstoringen voor scenario 1

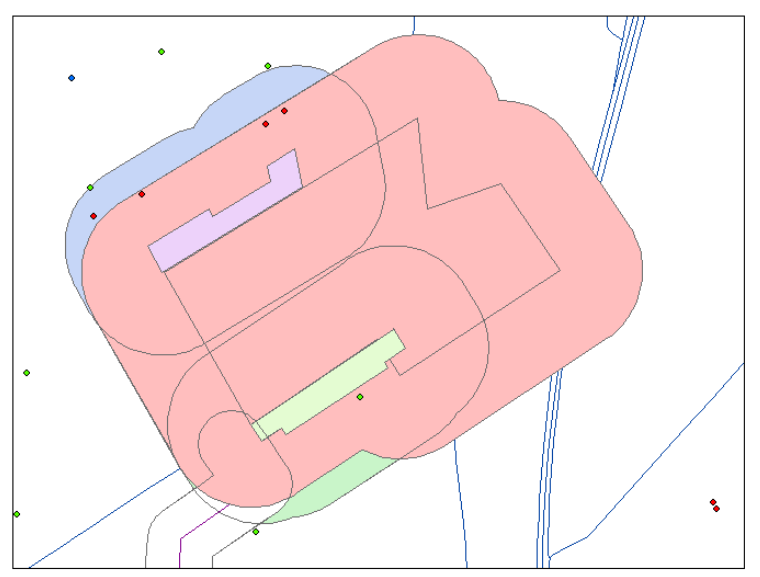

Legenda

- Grutto

- Slobeend

- Tureluur

$\square$ Unionsc1

Nekenweg_fas

Abbekerk

Abbekerk_met_verstoring_250m

nieuweweg

100m_zone_nieuwe_weg

Verstoring_EXTRA_Vekenwegfase

\section{Extra verstoring voor scenario 2}

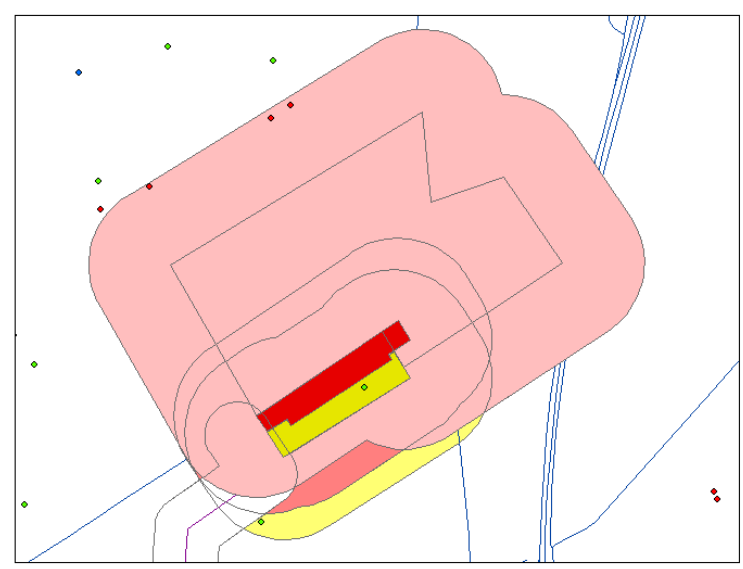

Legenda

- Grutto

- Slobeend

- Tureluur

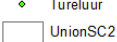

Vekenweg_fasel

Vekenweg_fasell

$\square$ Abbekerk_met_verstoring_250m

- nieuweweg

wegen

100 m_zone_nieuwe_weg

Verstoring_250m_Vekenwegfasel

verstoring_250m_Vekenweg_fasell

Extra verstoring voor scenario 3

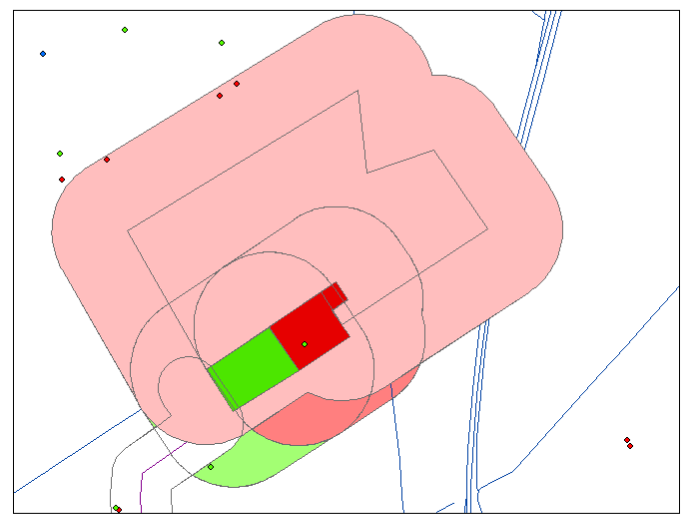

Legenda

- Grutto

- Slobeend

- Tureluur

Abbekerk

Vekenweg_ZW

Vekenweg_N

Abbekerk_met_verstoring_250

nieuweweg

wegen

verstoring_EXTRA_VekenwegNo

Figur 5 Weergave van het verstoorde gebied in de drie onderzochte scenario's. 


\subsection{Netto-verstoring plan Roskam}

De bestaande bebouwing en het bouwvlak voor de kavels zijn gedigitaliseerd en voorzien van een 200 $\mathrm{m}$ brede verstoringszone. Dit is de verstoringsafstand voor bebouwing buiten de bebouwde kom. Vervolgens is de verspreiding van weidevogels in 2014 samen met de verstoringszone en de ligging van percelen met agrarisch natuurbeheer op kaart gezet (Figuur 6).

De verstoringszone van de kavels langs de Dorpsstraat is kleiner dan de verstoring van de bestaande bebouwing. Net op de grens van de zone ligt een territorium van de tureluur, maar deze ligt al binnen de verstoringszone van de bestaande bebouwing. Als de stal naast de kavels verdwijnt, wordt het verstoorde oppervlak kleiner. Verder is er nog een aantal andere, minder gevoelige weidevogels aanwezig. Ook is te zien dat bij de begrenzing van geschikt gebied voor weidevogels (Sierdsema et al., 2013) kleinere verstoringsafstanden zijn gebruikt. Twee percelen met agrarisch natuurbeheer, in dit geval legselbeheer, lopen door tot dicht bij de agrarische bebouwing.

Zoals te zien is in Figuur 6, is er geen oppervlak dat door het nieuwe plan verstoord wordt en nog niet verstoord is. Er is dus netto geen verstoring.

\section{Verstoringszone \\ kavels dorpsstraat en bestaande bebouwing}
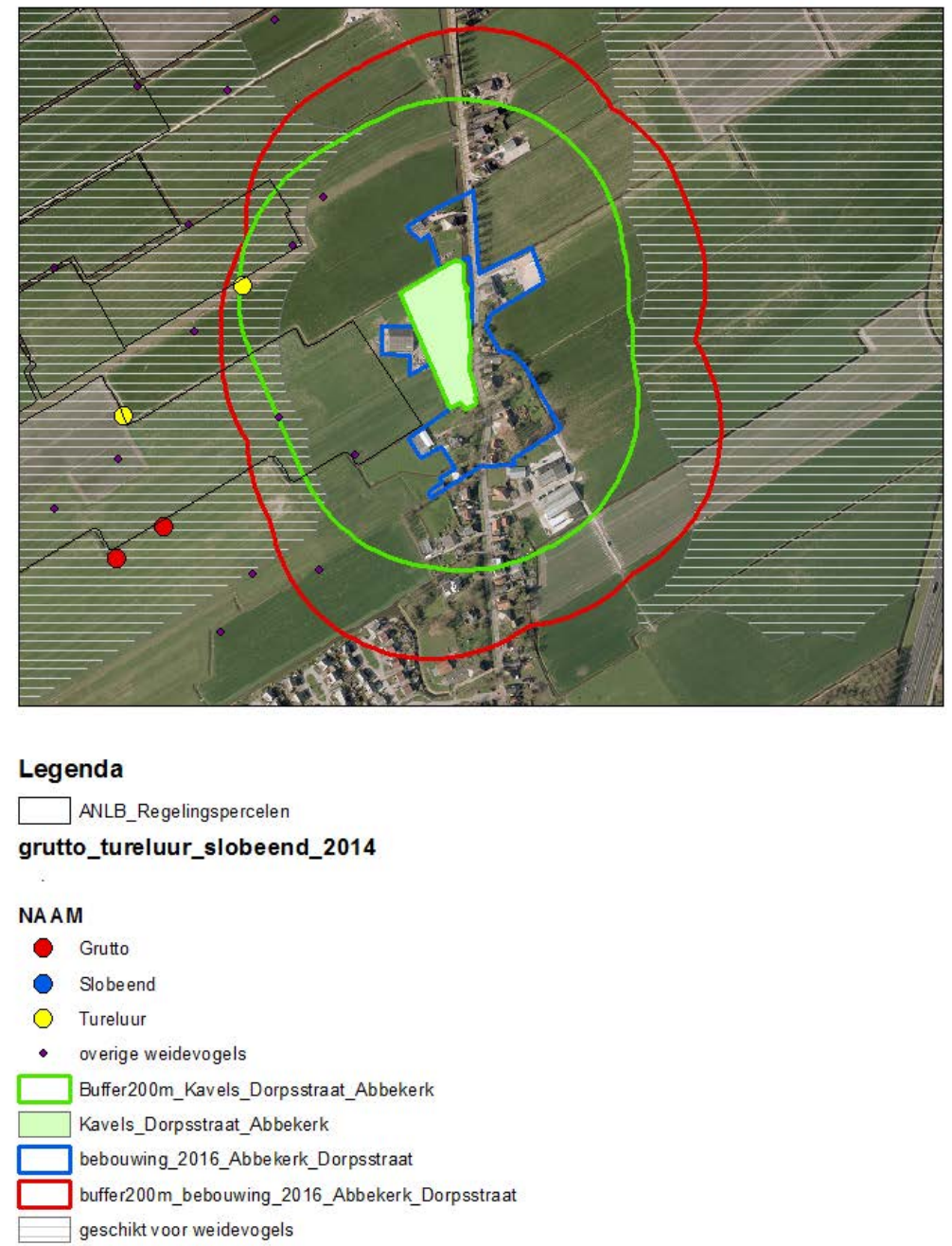

Figuur 6 Verstoorde zones in de bestaande situatie en na uitvoering van plan Roskam. 


\section{$4 \quad$ Compensatie}

Hoewel er dus juridisch gezien misschien wel, maar feitelijk geen sprake is van een netto verstorend effect, zitten er wel degelijk weidevogels in de bouwblokken en de verstoorde zones. Het gaat om minder gevoelige soorten, maar deze behoren ook tot de internationale doelsoorten van het provinciale beleid. Het is dan ook wenselijk om het netto-verlies aan weidevogelleefgebied te compenseren door een extra inspanning te leveren voor behoud van weidevogels op een plek waar dit nodig is, maar waar dit nu nog niet gebeurt. Die plekken zijn er ruimschoots voldoende in de kerngebieden bij Abbekerk gezien de inspanning die nu voor weidevogels wordt geleverd in de beoogde weidevogelkerngebieden (Figuur 7).

\section{Actuele betekenis voor weidevogels}

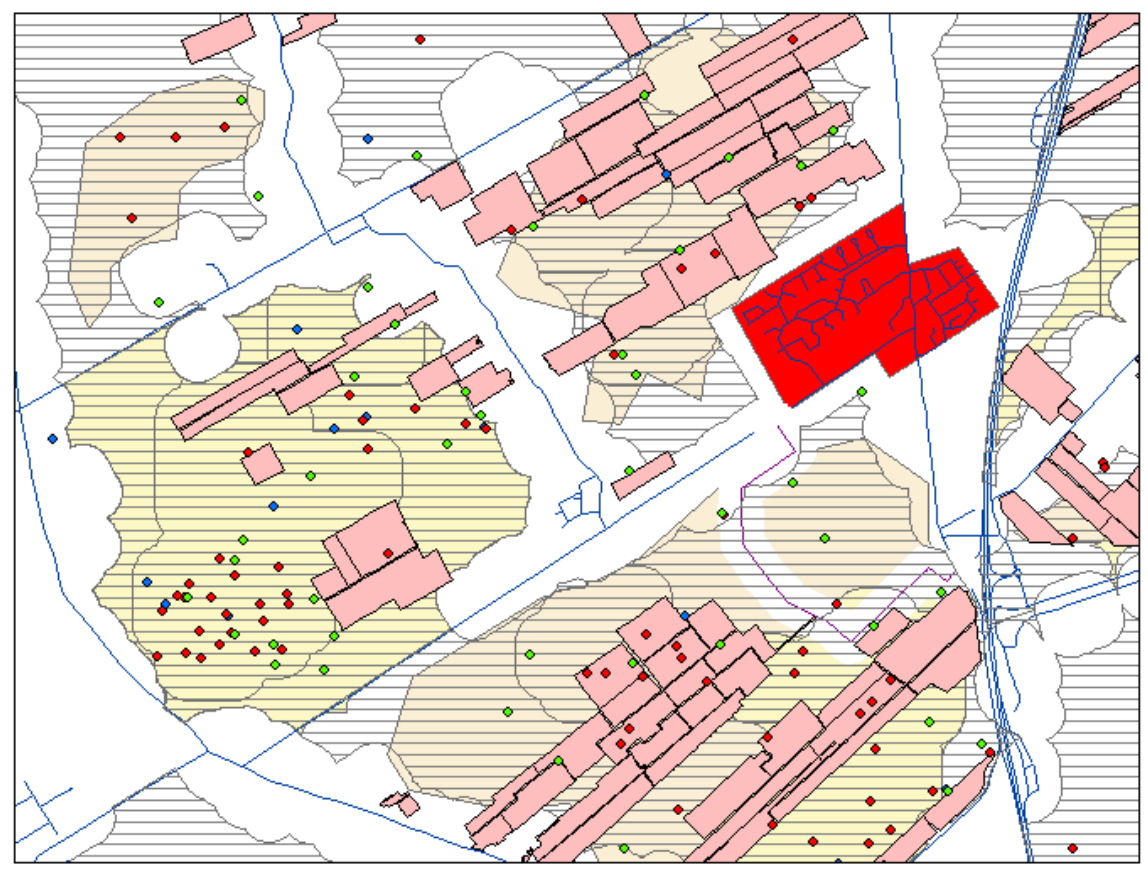

\section{Legenda}

- Grutto

- Slobeend

- Tureluur

Agrarisch natuurbeheer 2016 (1)

Agrarisch natuurbeheer 2016 (2)

geschikt voor weidevogels

- nieuweweg

$100 \mathrm{~m} \_z o n e \_n i e u w e \_w e g$

wegen

Kerngebieden_voorstel_Alterra

Kerngebieden_voorstel_LNH

Abbekerk

Figuur 7 Actuele inspanning voor behoud van weidevogels in de beoogde kerngebieden. 


\section{$5 \quad$ Weidevogelkerngebieden bij Abbekerk}

Volgens het natuurbeheerplan 2016 en de kaart behorend bij de provinciaal ruimtelijke verordening worden de telgebieden 22024 en 22041 als weidevogelgrasland in open landschap of als weidevogelleefgebieden aangeduid. Dit onderscheid is gebaseerd op weidevogelgegevens en criteria van voor 2014. Beide telgebieden voldeden op basis van de gegevens van 2014 al niet meer aan de daarvoor geldende eisen (Hoogenboom \& Visbeen, 2015). De vraag is of dat anno 2016 nog steeds het geval is. Om dit nader te onderzoeken, heeft de Gemeente Medemblik opdracht gegeven aan ecologisch onderzoeks- en adviesbureau Van der Goes en Groot een inventarisatie uit te voeren naar weidevogels in beide telgebieden bij Abbekerk in West-Friesland. De ligging van beide gebieden is weergegeven in Figuur 1. Telgebied 22024 is 298 ha groot (271 ha cultuurland), telgebied 22041 is 479 ha groot (440 ha cultuurland).

Bij een weidevogelinventarisatie worden gewoonlijk vier of vijf bezoeken uitgevoerd in de maanden april, mei en de eerste helft van juni. Bij het provinciale weidevogelonderzoek in West-Friesland in 2014 zijn vier bezoekrondes uitgevoerd. In 2014 is in beide gebieden geteld op 3 en 9 april (ronde 1), 17 en 22 april (ronde 2), 14 en 15 mei (ronde 3) en tot slot op 30 mei en 2 juni (ronde 4). Vanwege de late opdrachtverlening was het in 2016 alleen mogelijk de derde en vierde ronde uit te voeren (in mei). De eerste twee rondes die gebruikelijk zijn bij een weidevogelinventarisatie (in april) zijn niet uitgevoerd. De resultaten staan in Tabel 2.

Tabel 2

Aantal waargenomen weidevogel tijdens respectievelijk 4 en 2 bezoekrondes in 2014 en 2016 (Tabel uit: Groen 2016).

\begin{tabular}{|c|c|c|c|c|c|c|c|c|c|c|c|c|c|c|c|c|}
\hline \multirow[b]{3}{*}{ Naam / Ronde } & \multicolumn{8}{|c|}{ telgebied 22024} & \multicolumn{8}{|c|}{ telgebied 22041} \\
\hline & \multicolumn{5}{|c|}{2014} & \multicolumn{3}{|c|}{2016} & \multicolumn{5}{|c|}{2014} & \multicolumn{3}{|c|}{2016} \\
\hline & 1 & 2 & 3 & 4 & NT & 3 & 4 & NT & 1 & 2 & 3 & 4 & NT & 3 & 4 & NT \\
\hline Knobbelzwaan & 5 & 4 & 2 & 2 & 2 & & 1 & 1 & 2 & 3 & 1 & 3 & 3 & & 1 & 1 \\
\hline Bergeend & 8 & 5 & 1 & 2 & 1 & 4 & 1 & 4 & 10 & 5 & 6 & 2 & 6 & 8 & 9 & 8 \\
\hline Krakeend & 3 & 4 & 4 & 1 & 5 & 1 & 1 & 1 & 4 & 11 & 10 & 6 & 10 & 8 & 7 & 8 \\
\hline Wintertaling & & & & & & & & 0 & 2 & 3 & & & 0 & & & 0 \\
\hline Zomertaling & & 1 & 1 & & 1 & & & 0 & & & & & & & & 0 \\
\hline Slobeend & 2 & 2 & 2 & & 1 & 1 & & 1 & 3 & 2 & 7 & & 3 & 3 & & 3 \\
\hline Kuifeend & 4 & 3 & 2 & 4 & 4 & 6 & 7 & 7 & 14 & 21 & 19 & 10 & 10 & 12 & 12 & 12 \\
\hline Patrijs & & & 1 & & & & & 0 & & 2 & 1 & 2 & 1 & & & 0 \\
\hline Kwartel & & & & 1 & 1 & & & 0 & & & & & & & & 0 \\
\hline Scholekster & 26 & 36 & 28 & 24 & 29 & 23 & 27 & 28 & 28 & 36 & 38 & 28 & 37 & 37 & 44 & 40 \\
\hline Kievit & 25 & 29 & 28 & 30 & 29 & 26 & 19 & 27 & 53 & 53 & 69 & 39 & 56 & 68 & 37 & 56 \\
\hline Grutto & 6 & 14 & 7 & 8 & 8 & 15 & 5 & 15 & 39 & 20 & 27 & 12 & 27 & 19 & 13 & 19 \\
\hline Tureluur & 8 & 9 & 9 & 7 & 9 & 8 & 9 & 9 & 8 & 11 & 17 & 13 & 15 & 5 & 8 & 8 \\
\hline Graspieper & & 1 & & & 1 & & & 0 & & 3 & & & 3 & & & 0 \\
\hline Gele kwikstaart & 1 & 11 & 12 & 13 & 19 & 6 & 6 & 7 & 5 & 12 & 9 & 23 & 25 & 7 & 17 & 18 \\
\hline Totaal & 88 & 119 & 97 & 92 & 110 & 90 & 76 & 100 & 168 & 182 & 205 & 138 & 196 & 167 & 148 & 173 \\
\hline
\end{tabular}

Het totale aantal territoria van Slobeend, Grutto en Tureluur is in telgebied 22024 bepaald op 25 (18 in 2014) en in telgebied 22041 op 30 (45 in 2014). Voor beide gebieden samen heeft een afname van deze drie soorten plaatsgevonden van 63 territoria in 2014 naar 55 in 2016. De criteria voor selectie 
van kerngebieden zijn per 100 ha: $>3$ paren slobeend, $>15$ paren grutto, $>10$ paren tureluur en samen $>28$ paren.

De instapcriteria voor agrarisch natuurbeheer met als doel het ontwikkelen van een weidevogelkerngebied zijn: > 10 paren grutto per 100 ha, > 50 paren van grutto, tureluur en slobeend samen.

\section{Tabel 3}

Aantallen en dichtheden in paren per 100 ha op basis van de oppervlakte cultuurland in de beide telgebieden.

\begin{tabular}{|c|c|c|c|c|c|}
\hline Telgebied & Soort & N2014 & N2016 & p/km2 2014 & p/km2 2014 \\
\hline 22024 & grutto+tureluur+slobeend & 18 & 25 & 7 & 9 \\
\hline 22041 & grutto+tureluur+slobeend & 45 & 30 & 10 & 7 \\
\hline
\end{tabular}

Geen van beide telgebieden voldoet in 2014 noch in 2016 aan deze criteria (Tabel 3).

Deze criteria zijn vrij rigide toegepast en op gehele telgebieden. Het kaartbeeld dat de verspreiding van de vogels weergeeft, zegt veel meer. Alterra heeft de provincie in 2014 grenzen geadviseerd, gebaseerd op de kern van de verspreiding van de soorten, dus de gebiedsdelen waar die dichtheid gehaald wordt. Zulke kernen zullen nog bestaan binnen de telgebieden. Het is zaak die kernen, voorzien van een buffer van 400-600 m, te behouden. Als illustratie dient Figuur 8 uit het rapport van Visbeen et al. (2014).

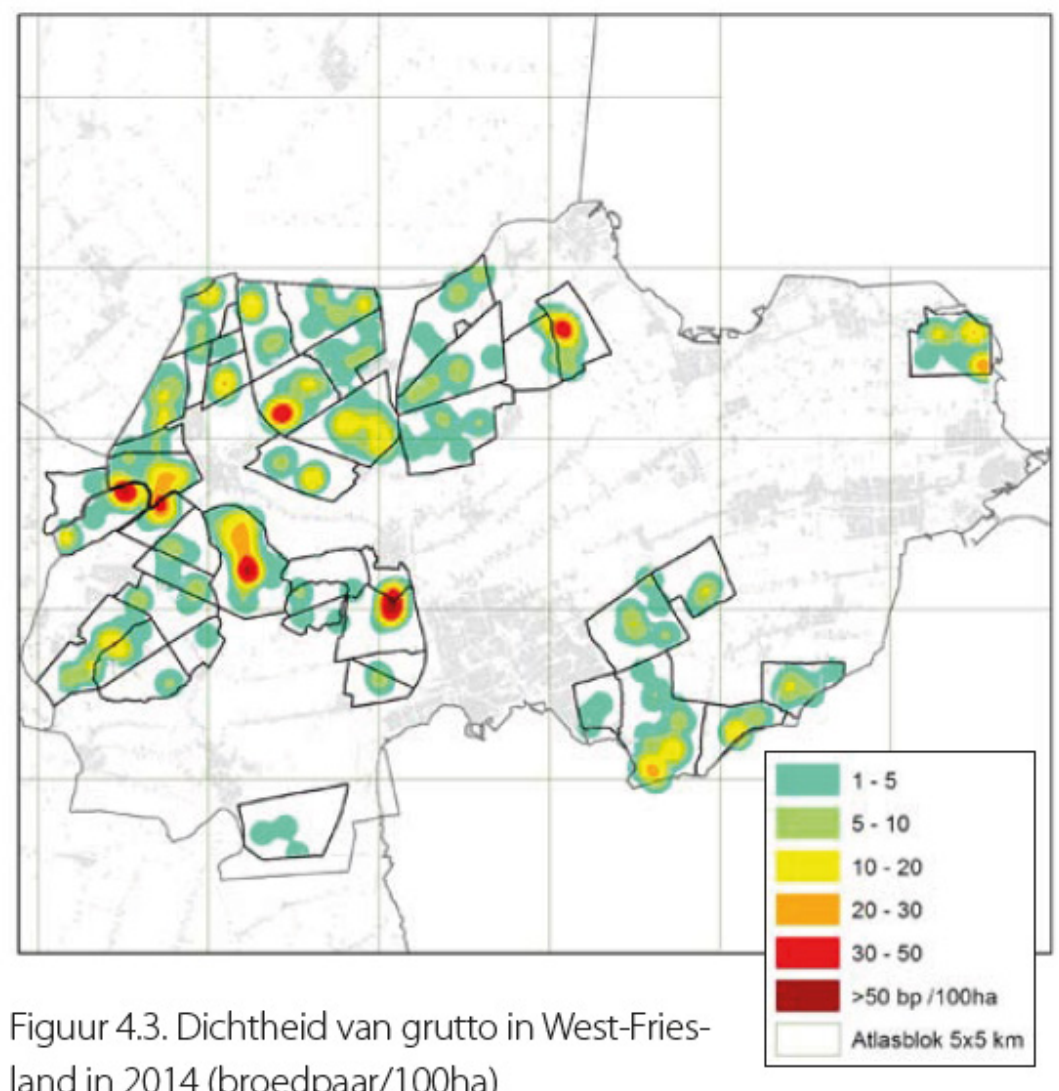

land in 2014 (broedpaar/100ha)

Figuur $8 \quad$ Ligging van verspreidingskernen van de grutto in West-Friesland op basis van de verspreiding in 2014. (Figuur uit Visbeen et al., 2014.) 


\section{Literatuur}

Groen, F.M. van, 2016. Weidevogelinventarisatie Abbekerk. Inventarisatie in twee telgebieden in 2016. Ecologische onderzoeks- en adviesbureau Van der Goes en Groot, Alkmaar.

Hoogeboom, D.M. \& F. Visbeen, 2014. Weidevogels in West- Friesland. Analyse weidevogelinventarisaties 2014 in relatie tot het provinciale beleid. Rapportnummer 14-033, Landschap Noord-Holland, Heiloo.

Schotman, A.G M., H. Sierdsema en Th.C.P. Melman, 2014. Kerngebieden voor weidevogels in de praktijk; Methodiek gebruikt voor maken voorstel kerngebieden Noord-Holland. Alterra Wageningen, UR (University \& Research centre), Wageningen

Sierdsema, H., A.G.M. Schotman, E.B. Oosterveld en Th.C.P. Melman, 2013. Weidevogelkerngebieden Noord-Holland; vergelijking van vier scenario's. Alterra-rapport 2435/Sovon-rapport 2435/A\&Wrapport 1899. Alterra, Wageningen.

Teunissen, W.A., A.G.M. Schotman, L.W. Bruinzeel, H. ten Holt, E.O. Oosterveld, H.H. Sierdsema, E. Wymenga en Th.C.P. Melman, 2012. Op naar kerngebieden voor weidevogels in Nederland. Werkdocument met randvoorwaarden en handreiking. Alterra-rapport 2344, Wageningen-UR. Nijmegen, SOVON Vogelonderzoek Nederland, SOVON-rapport 2012/21, Feanwâlden, Altenburg \& Wymenga ecologisch onderzoek, A\&W-rapport 1799.

Visbeen, F., D. Hoogeboom en K. Trimbos, 2014. Kerngebieden weidevogels Noord-Holland en een voorstel voor scholeksterleefgebied, juli 2014. Rapportnummer 14-021, Landschap Noord-Holland, Heiloo. 


\section{Bijlage 1 Uitvoeringsregeling natuur- compensatie Noord-Holland}

\section{Artikel 1}

1. Voor zover een bestemmingsplan voorziet in een nieuwe activiteit of wijziging van een bestaande activiteit overeenkomstig artikel 19, derde en vierde lid, of in een of meer ontwikkelingen overeenkomstig artikel 25, derde lid en vierde lid, van de Provinciale Ruimtelijke Verordening, maakt dat bestemmingsplan mogelijk dat de initiatiefnemer daarvan fysieke maatregelen neemt ter compensatie van de schade aan de ecologische hoofdstructuur een ecologische verbindingszone of een weidevogelgrasland in open landschap.

2. Indien de fysieke maatregelen niet in het bestemmingsplan mogelijk kunnen worden gemaakt, blijkt uit de toelichting van het bestemmingsplan wanneer en hoe fysieke compensatie planologisch wordt geregeld en dat het bevoegde gezag daaraan medewerking zal verlenen.

3. Indien fysieke maatregelen niet mogelijk zijn of indien het gebied dat wordt aangetast door een activiteit of ontwikkeling als bedoeld in het eerste lid plaatsvindt, niet groter is dan 3 hectare voor zover het betreft de ecologische hoofdstructuur of een ecologische verbindingszone en 5 hectare voor zover het betreft een weidevogelgrasland in open landschap, bepaalt het bestemmingsplan in afwijking van het bepaalde in het eerste lid dat de initiatiefnemer een bijdrage overeenkomstig artikel 7 voorafgaand aan de ontwikkeling aan de provincie Noord-Holland ter beschikking stelt ter uitvoering van compensatiemaatregelen.

4. Een bijdrage als bedoeld in het vorige lid wordt door de provincie gestort in de reserve groen ten behoeve van natuurcompensatiemaatregelen.

5. Het bepaalde in het derde lid is niet van toepassing op een activiteit of een combinatie van activiteiten als bedoeld in artikel 19, derde lid, onderdeel b, van de Provinciale Ruimtelijke Verordening.

\section{Artikel 2}

Uit de toelichting op een bestemmingsplan als bedoeld in artikel 1, eerste lid, blijkt dat de fysieke maatregelen ter compensatie van de aantasting van de ecologische hoofdstructuur of een ecologische verbindingszone:

a. plaatsvinden in nog niet gerealiseerde delen van de ecologische hoofdstructuur of ecologische verbindingszones of aansluitend aan al bestaande natuur in de ecologische hoofdstructuur;

b. plaatsvinden in de nabijheid van het aangetaste gebied tenzij aantoonbaar is dat dit niet mogelijk is;

c. plaatsvinden in een gebied dat minimaal gelijk is aan de oppervlakte van het aangetaste gebied;

d. de aangetaste wezenlijke kenmerken en waarden compenseren;

e. ten minste de inrichting van het gebied ten behoeve van de ontwikkeling van de gewenste natuur en ontwikkelingsbeheer van die natuur voor een duur van ten minste 5 jaar, en in geval van bos 10 jaar, omvatten.

\section{Artikel 3}

Uit de toelichting op een bestemmingsplan als bedoeld in artikel 1, eerste lid, blijkt dat de fysieke maatregelen ter compensatie van de aantasting van een weidevogelgrasland in open landschap:

a. plaatsvinden in een weidevogelgrasland in open landschap als bedoeld in artikel 25 van de Provinciale Ruimtelijke Verordening;

b. plaatsvinden in de nabijheid van het aangetaste gebied tenzij wordt aangetoond dat dit niet mogelijk is;

c. inrichtingsmaatregelen of actief weidevogelbeheer omvatten voor een bedrag gelijk aan de kosten voor beheer in een gebied dat minimaal gelijk is aan de oppervlakte van het aangetaste weidevogelgrasland in open landschap rekening houdende met een jaarlijkse rustperiode in de nestfase waarin agrarische werkzaamheden niet zijn toegestaan van 1 april tot en met 15 juni voor een periode van 30 jaar.

\section{Artikel 4}

De toelichting op een bestemmingsplan als bedoeld in artikel 1, eerste en tweede lid, waarin fysieke maatregelen worden bepaald, omvat een compensatieplan dat voldoet aan de volgende eisen: 
a. het plan bevat een kaart van een schaalniveau niet groter dan 1:10.000 waarop de locatie van de fysieke maatregelen plaatsvinden;

b. de fysieke maatregelen zijn concreet beschreven;

c. in het plan is aangegeven op welke momenten gedeputeerde staten de voortgang kunnen beoordelen;

d. het plan bevat een tijdschema voor realisatie van de compensatie waaruit blijkt dat initiatiefnemer de compensatie uiterlijk binnen twee jaar na de start van de uitvoering van de compensatieplichtige activiteit realiseert, tenzij in een compensatieovereenkomst als bedoeld in artikel 5 anders wordt bepaald;

e. het plan beschrijft het jaarlijkse beheer van het gebied en de voorwaarden waaraan een beheerder moet voldoen.

\section{Artikel 5}

1. Een bestemmingsplan als bedoeld in artikel 1, eerste, tweede of derde lid, bevat als bijlage een compensatieovereenkomst die is aangegaan tussen de initiatiefnemer en de provincie.

2. In een compensatieovereenkomst als bedoeld in het vorige lid is ten minste opgenomen:

a. welke rollen en verantwoordelijkheden de betrokken partijen hebben;

b. een financiële onderbouwing waaruit blijkt dat de uitvoering van de fysieke maatregelen is zeker gesteld en niet wordt gefinancierd uit middelen die beschikbaar zijn op grond van een subsidieregeling;

c. de termijn waarbinnen de uitvoering van compensatie moet zijn afgerond;

d. een boeteclausule die van toepassing is bij het niet, niet tijdig of onvolledig uitvoeren van de compensatie tenzij sprake is van een overeenkomst tussen overheden;

e. de verplichting om te melden wanneer de uitvoering van de compensatiemaatregelen starten;

f. de verplichting om gedeputeerde staten jaarlijks te informeren over de voortgang.

3. Voor het verschuldigd zijn van een boete als bedoeld in het vorige lid is geen ingebrekestelling nodig.

4. Het boetebedrag wordt gestort in een provinciale reserve groen ten behoeve van natuurcompensatiemaatregelen. Het boetebedrag is op het moment van vaststelling ten minste gelijk aan 150 procent van alle directe en indirecte kosten die samenhangen met de betrokken compensatie.

\section{Artikel 6}

1. Een bijdrage als bedoeld in artikel 1, derde lid, omvat voor de Ecologische Hoofdstructuur en een ecologische verbindingszone de volgende kostenelementen:

a. kosten van de aanschaf van vervangende grond;

b. kosten van de basisinrichting;

c. kosten van ontwikkelingsbeheer gedurende de ontwikkelingstijd, afhankelijk van het type natuur dat wordt ontwikkeld;

d. kosten voor de planontwikkeling en planuitvoering, deze zijn bepaald op 20 procent van de kosten genoemd bij $a, b$ en $c$.

2. Een bijdrage als bedoeld in artikel 1, derde lid, omvat voor een weidevogelgrasland in open landschap de volgende kostenelementen:

a. de kosten voor 30 jaar actief weidevogelbeheer voor een gebied dat minimaal gelijk is aan de oppervlakte van het aangetaste weidevogelgrasland in open landschap rekening houdende met een jaarlijkse rustperiode in de nestfase waarin agrarische werkzaamheden niet zijn toegestaan jaarlijks van 1 april tot en met 15 juni;

b. de kosten voor de planontwikkeling en planuitvoering; deze zijn bepaald op 20 procent van de kosten genoemd bij a.

\section{Artikel 7}

1. De beleidsregel compensatie natuur en recreatie Noord-Holland van 17 december 2007, nr. 200776280 (Pb 2008, 10) wordt ingetrokken.

2. Deze regeling treedt in werking met ingang van de dag na de datum van uitgifte van het provinciaal blad waarin zij wordt geplaatst.

3. Deze regeling wordt aangehaald als: Uitvoeringsregeling natuurcompensatie Noord-Holland. Haarlem, 2 december 2014.

Gedeputeerde Staten van Noord-Holland, J.W. Remkes, voorzitter.

G.E.A. van Craaikamp, provinciesecretaris. 
Alterra Wageningen UR

\section{Postbus 47}

6700 AA Wageningen

T 0317480700

www.wageningenUR.nl/alterra

Alterra-rapport 2732

ISSN 1566-7197
Alterra Wageningen UR is hét kennisinstituut voor de groene leefomgeving en bundelt een grote hoeveelheid expertise op het gebied van de groene ruimte en het duurzaam maatschappelijk gebruik ervan: kennis van water, natuur, bos, milieu, bodem, landschap, klimaat, landgebruik, recreatie etc.

De missie van Wageningen UR (University \& Research centre) is 'To explore the potential of nature to improve the quality of life'. Binnen Wageningen UR bundelen 9 gespecialiseerde onderzoeksinstituten van stichting DLO en Wageningen University hun krachten om bij te dragen aan de oplossing van belangrijke vragen in het domein van gezonde voeding en leefomgeving. Met ongeveer 30 vestigingen, 6.000 medewerkers en 9.000 studenten behoort Wageningen UR wereldwijd tot de aansprekende kennisinstellingen binnen haar domein. De integrale benadering van de vraagstukken en de samenwerking tussen verschillende disciplines vormen het hart van de unieke Wageningen aanpak. 


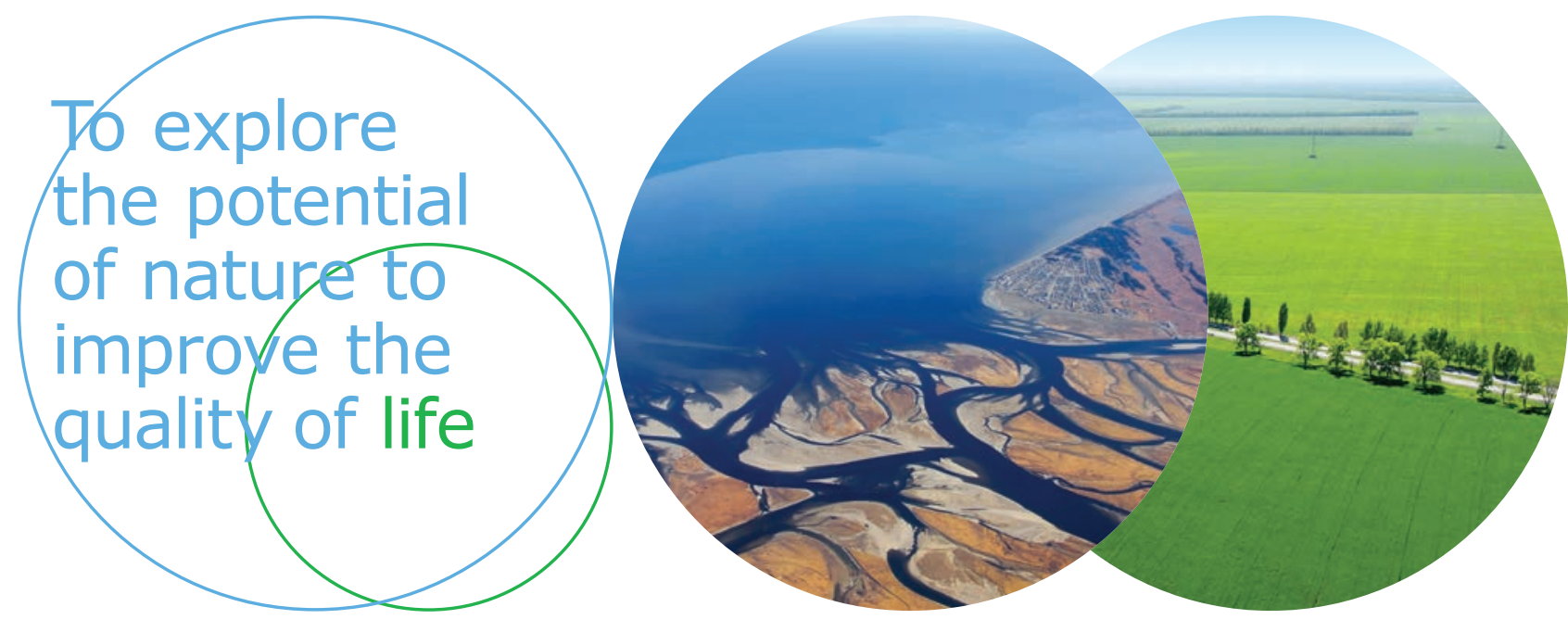

Alterra Wageningen UR

Postbus 47

6700 AA Wageningen

T 317480700

www.wageningenUR.nl/alterra

Alterra-rapport 2732

ISSN 1566-7197
Alterra Wageningen UR is hét kennisinstituut voor de groene leefomgeving en bundelt een grote hoeveelheid expertise op het gebied van de groene ruimte en het duurzaam maatschappelijk gebruik ervan: kennis van water, natuur, bos, milieu, bodem, landschap, klimaat, landgebruik, recreatie etc.

De missie van Wageningen UR (University \& Research centre) is 'To explore the potential of nature to improve the quality of life'. Binnen Wageningen UR bundelen 9 gespecialiseerde onderzoeksinstituten van stichting DLO en Wageningen University hun krachten om bij te dragen aan de oplossing van belangrijke vragen in het domein van gezonde voeding en leefomgeving. Met ongeveer 30 vestigingen, 6.000 medewerkers en 9.000 studenten behoort Wageningen UR wereldwijd tot de aansprekende kennisinstellingen binnen haar domein. De integrale benadering van de vraagstukken en de samenwerking tussen verschillende disciplines vormen het hart van de unieke Wageningen aanpak. 